\title{
Corals, Canyons, and Conservation: Science Based Fisheries Management Decisions in the Eastern Bering Sea
}

\author{
Steve A. MacLean ${ }^{1 *}$, Christopher N. Rooper ${ }^{2}$ and Michael F. Sigler ${ }^{3}$ \\ ${ }^{1}$ North Pacific Fishery Management Council, Anchorage, AK, USA, ${ }^{2}$ Alaska Fisheries Science Center, National Oceanic and \\ Atmospheric Administration (NOAA), Seattle, WA, USA, ${ }^{3}$ Alaska Fisheries Science Center, National Oceanic and \\ Atmospheric Administration (NOAA), Juneau, AK, USA
}

OPEN ACCESS

Edited by:

Leslie Cornick,

Alaska Pacific University, USA

Reviewed by:

Lorenzo Angeletti,

Institute of Marine Sciences, Italy

Andrew M. Fischer,

University of Tasmania, Australia

*Correspondence:

Steve A. MacLean

steve.maclean@noaa.gov

Specialty section: This article was submitted to

Marine Conservation and Sustainability,

a section of the journal Frontiers in Marine Science

Received: 03 March 2017 Accepted: 27 April 2017 Published: 12 May 2017

Citation:

MacLean SA, Rooper CN and Sigler MF (2017) Corals, Canyons, and Conservation: Science Based Fisheries Management Decisions in

the Eastern Bering Sea.

Front. Mar. Sci. 4:142.

doi: 10.3389/fmars.2017.00142
When making science matter for conservation, marine conservation practitioners, and managers must be prepared to make the appropriate decision based on the results of the best available science used to inform it. For nearly a decade, many stakeholders encouraged the North Pacific Fishery Management Council to enact protections for deep-sea corals in several canyons in the Eastern Bering Sea slope. In 2014, at the request of the Council, the National Marine Fisheries Service, Alaska Fisheries Science Center conducted a strip-transect survey along the Eastern Bering Sea slope to validate the results of a model predicting the occurrence of deep-sea coral habitat. More than 250,000 photos were analyzed to estimate coral, sponge, and sea whip abundance, distribution, height, and vulnerability to anthropogenic damage. The results of the survey confirmed that coral habitat and occurrence was concentrated around Pribilof Canyon and the adjacent slope. The results also confirmed that the densities of corals in the Eastern Bering Sea were low, even where they occurred. After reviewing the best available scientific information, the Council concluded that there is no scientific evidence to suggest that deep-sea corals in the Eastern Bering Sea slope or canyons are at risk from commercial fisheries under the current management structure, and that special protections for deep-sea corals were not warranted.

Keywords: deep-sea corals, undersea canyons, eastern Bering Sea, fishing impacts, fishery management

\section{INTRODUCTION}

The theme of the 4th International Conservation Congress was "Making Science Matter." When making science matter for conservation, marine conservation practitioners, and managers must be prepared to make appropriate decisions based on the results of the best available science used to inform it. The North Pacific Fishery Management Council (Council) was established by the Magnuson-Stevens Fishery Conservation and Management Act (MSA), and for the last several decades has worked with the National Oceanic and Atmospheric Administration (NOAA) National Marine Fisheries Service (NMFS) Alaska Region (AKRO), and Alaska Fisheries Science Center (AFSC) to ensure that the best available science informs the decisions made by the Council, and enacted in regulation.

Management of Federal fisheries in Alaska is directed by the MSA to ensure sustainable harvests of Alaska's fishery resources. The MSA also, importantly, allows the Council to establish 
conservation areas and regulations to protect habitat and other biological or ecological factors that contribute to a healthy marine ecosystem. Specifically, concerning undersea canyons and deep-water corals, the Council could implement provisions of Essential Fish Habitat (EFH), including Habitat Areas of Particular Concern (HAPC), and deep-sea coral authorities. This would allow the Council to establish habitat protection areas if the best available science indicated that protections were necessary to ensure their conservation.

The Council has been actively involved in benthic habitat protection for many years. In 2005, the Council adopted several closures to address the impacts of bottom trawling on benthic habitats, including protections for coral communities and in the Aleutian Islands and Gulf of Alaska (71 FR 36694). In 2006, the Council considered whether additional protections were necessary for five submarine canyons that incise the southeastern Bering Sea shelf (Figure 1). Some undersea canyons are known to be areas of high benthic biomass and productivity (Vetter and Dayton, 1998; De Leo et al., 2010), and the Council has received requests to consider protections for canyons in the Bering Sea slope for several years. A review by the AFSC (McConnaughey et al., 2006) concluded that although there are extensive geological studies of submarine canyons in the EBS, very little biological information was available to assess the value of canyon habitat for specific species, and the available data did not suggest that EFH or HAPC designation was appropriate. McConnaughey et al. (2006) also called for systematic studies of habitats and coordinated biological sampling to better understand the vulnerability of those habitats to anthropogenic disturbance.

Miller et al. (2012), partly in response to the recommendation for dedicated surveys, conducted video transects in Zhemchug and Pribilof canyons to evaluate the density of structureforming corals and sponges and to evaluate the use of corals, sponges, and boulders as habitat by demersal fishes. Miller et al. (2012) concluded that the canyons are dominated by low relief soft substrate, which makes the corals an important habitat element that provides vertical relief. Further, Miller et al. (2012) concluded that Pribilof and Zhemchug canyons harbor "high densities of slow-growing corals that form the foundation of complex communities." The Council then requested a review of all available information to assess the importance of Bering Sea canyons as unique coral and sponge habitats, habitats for fish species managed under a Fishery Management Plan (FMP), and the patterns of fishing activities in the area.

Sigler et al. (2015) compiled data from the eastern Bering Sea that included trawl survey data on fish and invertebrate distributions and observations of ocean conditions and benthic habitat, and analyzed them using multivariate techniques to determine if the five major eastern Bering Sea canyons (Figure 1) are distinguishable from the adjacent slope. Sigler et al. (2015) concluded that the major characteristics structuring fish and invertebrate communities were depth, latitude, and sediment rather than submarine canyons, [i.e., the five major canyons do not show distinguishing biological characteristics (fish, coral, and sponge distribution) that separate them from the adjacent slope habitat]. However, although the canyons themselves were not good predictors for the presence of corals, Sigler et al. (2015) predicted that about $25 \%$ of the Bering Sea slope coral habitat occurs in Pribilof Canyon, which comprises only about $10 \%$ of the total slope area. The numerical density of corals in Pribilof Canyon was low when compared to areas in the Aleutian Islands where coral protections are in place $\left(0.28\right.$ colonies* $\mathrm{m}^{-2}$ vs. 1.23 colonies* $\mathrm{m}^{-2}$ ) (Stone, 2006; Miller et al., 2012). Nevertheless, the Council requested that the AFSC conduct a field study to identify and validate areas of coral concentrations in the Bering Sea slope, and to identify and determine the density and size of coral and sponge taxa present in the Bering Sea slope.

Rooper C. N. et al. (2016) conducted an underwater camera survey of the eastern Bering Sea slope and outer shelf as an independent test of species distribution modeling of deep-sea corals, sponges, and sea whips based on bottom trawl survey data. In the Rooper C. N. et al. (2016) study, 250 transects were sampled along the eastern Bering Sea outer shelf and slope from Bering Canyon to Pervenets Canyon. Depths sampled ranged from 90 to $808 \mathrm{~m}$, with a median depth of $276 \mathrm{~m}$. Over $97 \%$ of the images of the seafloor were classified as containing only unconsolidated substrate (mud, sand, gravel, pebble, mixed coarse material). The remaining images contained some sort of rocky substrate, but rocky substrate was predominant in only $1.4 \%$ of the images. Corals occurred on 32 of 250 survey transects, and did not occur in the transects sampled in Bering or Pervenets Canyon, or the regions between Bering and Pribilof canyons or between Zhemchug and Pervenets canyons (Figure 1). Corals were identified by Rooper C. N. et al. (2016) to three families (Primnoidae, Plexauridae, and Isididae), and two genera (Plumarella, and Swiftia). The densities of corals found were very low, and ranged from 0 to 0.28 individuals ${ }^{*} \mathrm{~m}^{-2}$ (mean 0.005 , SE 0.002). The highest densities of corals were found in Pribilof Canyon, and the adjacent slope to the northwest, as documented in Sigler et al. (2015). The height of corals varied by taxonomic group, and averaged less than $20 \mathrm{~cm}(2-116$ $\mathrm{cm})$. Evidence of fishing was found on $0.8-7.6 \%$ of transects, depending on the type of evidence. Trawl net fragments were seen on $0.8 \%$ of transects, longline, or crab gear on $4.4 \%$, and trawl tracks were seen on $7.6 \%$ of transects. In total, evidence of fishing was seen on $12.8 \%$ of transects. Damaged taxa (mostly sea whips) were observed on $27.2 \%$ of transects. Damaged taxa combined with evidence of fishing occurred on $3.2 \%$ of transects (8 of 250). Of these 8 transects, 7 had damaged sea whips, 1 had a damaged demosponge. No damaged corals were seen.

\section{INTERPRETATION AND APPLICATION TO MANAGEMENT}

Since 2006, the Council has been encouraged by members of the public and conservation organizations to consider protections for undersea canyons in the Bering Sea slope. In response, the Council initiated several studies of existing data, and requested additional studies to gather new data on the distribution, abundance, and vulnerability of deep-sea corals in the Bering Sea slope and canyons, and their association with fish species in the Bering Sea. The data and results presented in McConnaughey 


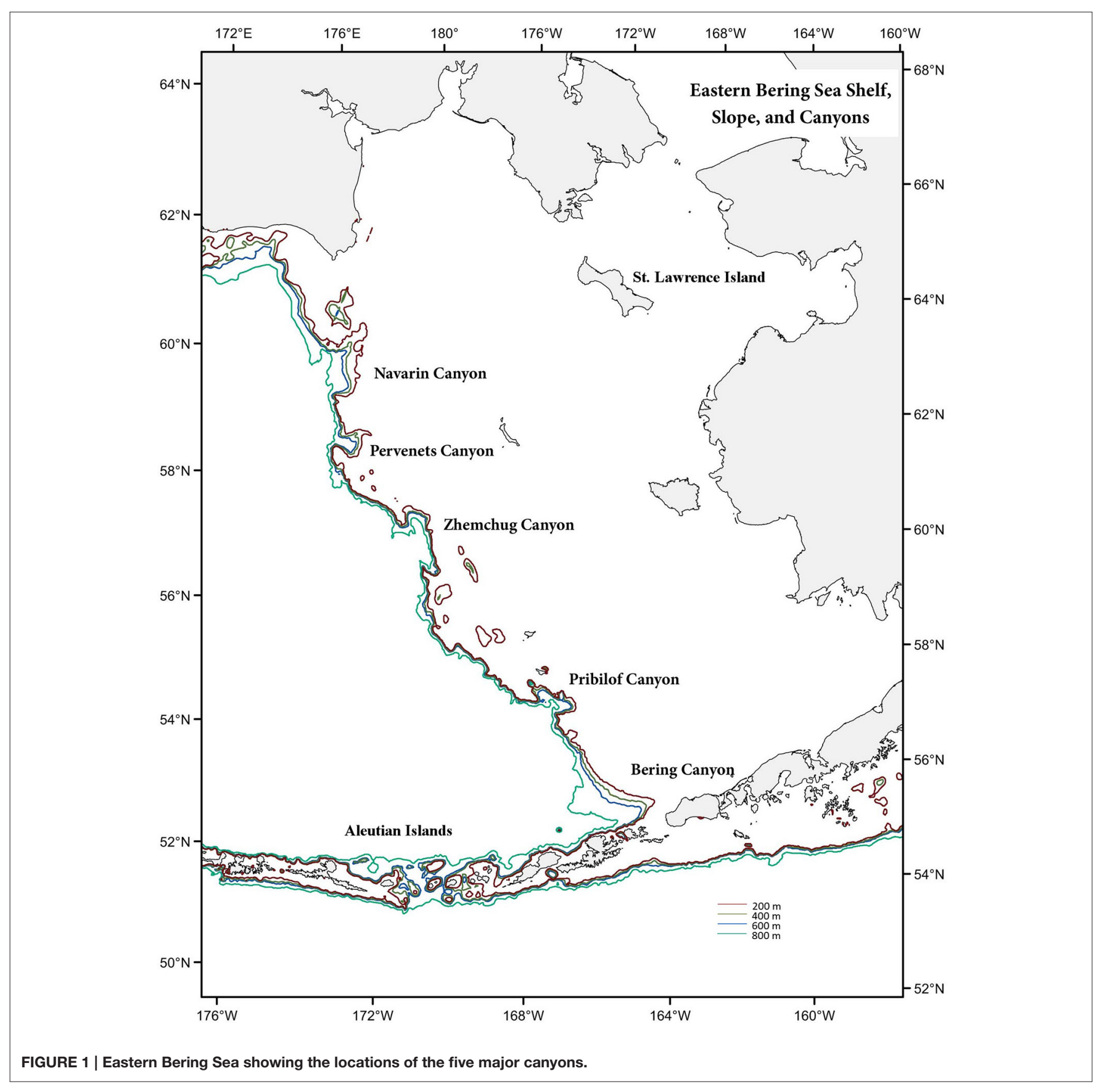

et al. (2006); Miller et al. (2012); Rooper et al. (2015); Sigler et al. (2015); Rooper C. et al. (2016); Rooper C. N. et al. (2016), and in discussion papers and presentations to the Council represent the information available to the Council to determine the best management decisions regarding conservation protections for canyons. When the Council requested field studies from the AFSC to identify and validate areas of coral concentrations and identify and determine the density and size of coral and sponge taxa present in the Bering Sea slope, the Council identified the purpose of the action to "determine whether and how the Council should...protect known, significant concentrations of deep-sea corals in the Pribilof Canyon and the adjacent slope from fishing impacts." To make that determination, the Council needed two types of information:

1 Are deep-sea corals present in and directly adjacent to Pribilof Canyon in significant densities?

2 Are the corals present in that area vulnerable to impacts from commercial fishing?

Results from Rooper C. N. et al. (2016) show that deepwater corals are present along the Bering Sea slope, with average densities of 0.005 individuals $\mathrm{m}^{-2}$. The densities and 
heights of corals were highest in and adjacent to Pribilof Canyon. There were significant positive correlations between fish density and presence of coral for some rockfish species and king crab. Evidence of fishing gear or damage to benthic invertebrates occurred at $37 \%$ of transects. The question before the Council, from their purpose statement, was whether the corals in the Bering Sea canyons were present in known, significant concentrations, and whether they are vulnerable to fishing impacts.

\section{Are Deep-Sea Corals Present in Significant Densities?}

A useful comparison is to consider the density of structure forming invertebrates on the eastern Bering Sea slope and shelf to other areas of Alaska where similar studies have been conducted. In 2012, a randomized stereo camera survey was conducted in the eastern and central Aleutian Islands and Bowers Bank using the same methodology and covering a similar depth range as the eastern Bering Sea study (C. Rooper, AFSC-RACE Division, unpublished data). In the Aleutians, coral densities averaged 0.11 individuals ${ }^{*} \mathrm{~m}^{-2}$, and ranged as high as 1.3 individuals $\mathrm{m}^{-2}$. On Bowers Bank, coral densities ranged as high as 1.67 individuals $\mathrm{m}^{-2}$, and averaged 0.21 individuals $\mathrm{m}^{-2}$ (Figure 2). A randomized survey conducted in 2010 at two of the protected areas in the Gulf of Alaska identified above (71 FR 36694) estimated average density of corals at 0.10 individuals $\mathrm{m}^{-2}$, and a maximum density of 1.2 individuals ${ }^{*} \mathrm{~m}^{-2}$ (C. Rooper, AFSC-RACE Division, unpublished data). The density of corals estimated from these other studies are much higher than the density estimated for the eastern Bering Sea $\left(0.005\right.$ individuals $\left.\mathrm{m}^{-2}\right)$. Other published density estimates for coral are available for Pribilof and Zhemchug canyons from a study conducted in 2007 (Miller et al., 2012), where densities of gorgonian corals in Pribilof Canyon were estimated at 0.73 individuals ${ }^{*} \mathrm{~m}^{-2}$, and estimates in Zhemchug Canyon were 0.13 individuals $\mathrm{m}^{-2}$. These density estimates are higher than those

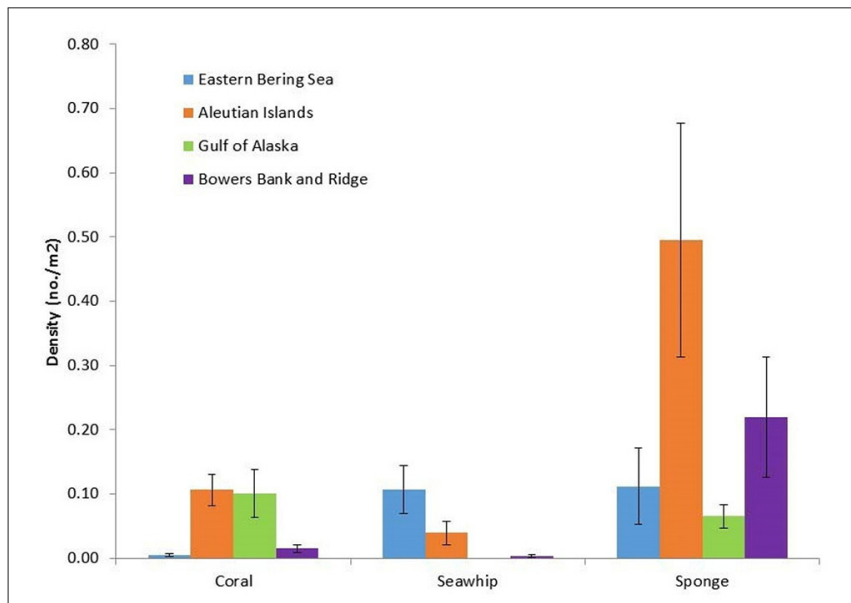

FIGURE 2 | Comparison of density of corals, seawhips, and sponges in the Eastern Bering Sea, Aleutian Islands, Gulf of Alaska, and Bowers Bank and Ridge, Alaska. reported by Rooper C. N. et al. (2016), likely due to differences in sampling design. While Rooper C. N. et al. (2016) randomized transects, Miller et al. (2012) placed transects systematically where coral was likely to be seen based on prior knowledge. Additionally, their sample size was low, transects were also sometimes clustered, and individual frames were treated as an independent sample, rather than each transect.

Coral densities likely differ between the Aleutian Islands/Bowers Bank, Gulf of Alaska, and Eastern Bering Sea because of differences in the amount of appropriate substrates available for colonization. In the studies above that performed random camera surveys in the Aleutian Islands, Bowers Bank, and Gulf of Alaska, the percentage of transects with rocky habitat (cobble, boulder, exposed bedrock) present somewhere along the transect was 63,42 , and $58 \%$, respectively (C. Rooper, AFSC-RACE Division, unpublished data), compared to $3.2 \%$ for the Eastern Bering Sea slope (Rooper C. N. et al., 2016). Deep-sea corals require rocky habitats on which to settle, and results from the Eastern Bering Sea show a distinct lack of appropriate habitat (Rooper C. N. et al., 2016), which explains the low density of deep-sea corals in Pribilof and Zhemchug canyons.

\section{Are Deep-Sea Corals in the Area Vulnerable to Fishing Impacts?}

The vulnerability of deep-sea corals to anthropogenic impact is a function of their density and height, and the rate of impact. Rooper C. et al. (2016) modeled the upper quartiles of coral height and density, and compared those areas to fishing effort (all gears) from 2003 to 2014. Fishing effort for hook-andline, pots, and jig fishing gears in predicted coral habitat was $<1 \%$ combined for all years. Fishing effort for pelagic trawls ranged from 11 to $18 \%$ from 2002 to 2007 , and $0-5 \%$ for 2009-2014. The values for non-pelagic trawl ranged from 1 to $6 \%$ during 2003-2014. The overlap of areas with highest coral vulnerability and fishing effort was low. Although the relative abundance and size of corals in Pribilof Canyon would make them more vulnerable to fishing impact than in other areas of the Eastern Bering Sea, the low current overall fishing effort in the area reduces the likelihood of impact for those corals.

\section{Council Management Decision}

For nearly a decade, the Council was involved in a public process to understand the distribution and abundance of deep-sea corals in the eastern Bering Sea, and whether habitat protections were necessary to conserve them. The Council reviewed existing studies (McConnaughey et al., 2006; Stone, 2006; Miller et al., 2012; Sigler et al., 2015), and requested new studies (Rooper C. et al., 2016) when data were lacking. Direct observation and analysis showed that the density of corals, the amount of available habitat, and fishing pressure where corals exist in the eastern Bering Sea is low (Rooper C. N. et al., 2016), in contrast to the Aleutian Islands where coral density and habitat availability are high (Stone, 2006) and habitat protections for corals already exist. Based on the analysis of the best available data, the Council concluded that deep-sea corals on the eastern 
Bering Sea slope and canyons are not at risk under current fishery management, and additional habitat protections are not necessary. This science-based decision is consistent with datadriven, ecosystem based fishery management principles, which hold that protections should be enacted where they are likely to be most effective. If marine conservation practitioners and resource managers are committed to "making science matter," then they

\section{REFERENCES}

De Leo, F. C., Smith, C. R., Rowden, A. A., Bowden, D. A., and Clark, M. R. (2010). Submarine canyons: hotspots of benthic biomass and productivity in the deep sea. Proc. Biol. Sci. 277, 2783-2792. doi: 10.1098/rspb.2010.0462

McConnaughey, R. A., Amend, M., Berger, J., Busby, M., Campbell, G., Hoff, J., et al. (2006). A Review of Scientific Information Related to Bering Sea Canyons and Skate Nursery Areas. North Pacific Fishery Management Council, Anchorage, AK.

Miller, R. J., Hocevar, J., Stone, R. P., and Fedorov, D. V. (2012). Structure-forming corals and sponges and their use as fish habitat in Bering Sea submarine canyons. PLoS ONE 7:e33885. doi: 10.1371/journal.pone.0033885

Rooper, C., Smeltz, S., Harris, B., Olson, J., and Sigler, M. (2016). Fishing Effort in Predicted Coral Habitat in the Eastern Bering Sea. Report to the North Pacific Fishery Management Council.

Rooper, C. N., Sigler, M., Goddard, P., Malecha, P., Towler, R., Williams, K., et al. (2015). Validation of Models of the Distribution of Structure-Forming Invertebrates in the Eastern Bering Sea Using an Underwater Stereo Camera. Report to the North Pacific Fishery Management Council.

Rooper, C. N., Sigler, M. F., Goddard, P., Malecha, P., Towler, R., Williams, K., et al. (2016). Validation and improvement of species distribution models for must be prepared to make the appropriate decision based on the best available science.

\section{AUTHOR CONTRIBUTIONS}

SM is the primary author. CR lead camera surveys in the EBS. MS and CR modeled coral habitat in EBS.

structure-forming invertebrates in the eastern Bering Sea with an independent survey. Mar. Ecol. Prog. Ser. 551, 117-130. doi: 10.3354/meps11703

Sigler, M. F., Rooper, C. N., Huff, G. R., Stone, R. P., McConnaughey, R. A., and Wilderbuer, T. K. (2015). Faunal features of submarine canyons on the eastern Bering Sea slope. Mar. Ecol. Prog. Ser. 526, 21-40. doi: 10.3354/meps11201

Stone, R. P. (2006). Coral habitat in the Aleutian Islands of Alaska: depth distribution, fine-scale species associations, and fisheries interactions. Coral Reefs 25, 229-238. doi: 10.1007/s00338-006-0091-Z

Vetter, E. W., and Dayton, P. K. (1998). Macrofaunal communities within and adjacent to a detritus-rich submarine canyon system. Deep Sea Res. II 45, 25-54.

Conflict of Interest Statement: The authors declare that the research was conducted in the absence of any commercial or financial relationships that could be construed as a potential conflict of interest.

Copyright (C) 2017 MacLean, Rooper and Sigler. This is an open-access article distributed under the terms of the Creative Commons Attribution License (CC BY). The use, distribution or reproduction in other forums is permitted, provided the original author(s) or licensor are credited and that the original publication in this journal is cited, in accordance with accepted academic practice. No use, distribution or reproduction is permitted which does not comply with these terms. 